\title{
PERANCANGAN DATA WAREHOUSE DAN PENERAPAN TEKNIK CLUSTERING SPATIAL PADA WESEL: STUDI KASUS PT XXX
}

\author{
Arief Dwi Hartadi; Oktalia Juwita \\ Information Systems Department, School of Information Systems, Binus University \\ Jl. K.H. Syahdan No. 9, Palmerah, Jakarta Barat 11480 \\ ariefdwihartadi@gmail.com; oktalia.juwita@gmail.com
}

\begin{abstract}
By setting up the right service and product for the customer, the company may increase its marketing effectiveness as well as sales. For that purpose, information on company's product and sales is highly needed in order to help on decision making process, which expectedly enables company to create value and eventually gain competitive advantage. This research attempts to develop a Data warehouse for PT XXX, which is expected to exhibit useful information for the company without disturbing its operational system. The Data warehouse is developed with Oracle 11g. Apart from that, this research also aims to gather information and knowledge with spatial database. The data mining is conducted by using WEKA application, which compares the algorithm of DBSCAN, K-Means, and EM clustering. Data mining from the spatial data is expected to create area map which indicates sales rate of PT Pos Indonesia's products. Through this it is hoped that the company may focus more in marketing certain product with particular advantage in one particular area to produce effectiveness. The research outcome indicates that the Data warehouse being developed has already managed to exhibit the receipt report of postal money order (wesel pos), retail stock, as well as retail sales.
\end{abstract}

Keywords: competitive advantage, Data Warehouse, clustering technique, spatial database,

\begin{abstract}
ABSTRAK
Menentukan produk layanan yang tepat sasaran terhadap pelanggan dapat meningkatkan efektifitas pemasaran dan meningkatkan tingkat penjualan. Untuk hal tersebut, dibutuhkan informasi mengenai produk dan penjualan dari perusahaan yang dapat digunakan dalam membuat keputusan, sehingga dapat menciptakan nilai yang pada akhirnya dapat memberikan competitive advantage bagi perusahaan. Penelitian ini bertujuan untuk mengembangkan Data warehouse bagi PT XXX. Data warehouse ini diharapkan bisa menampilkan informasi yang berguna bagi perusahaan, tanpa mengganggu sistem operasional. Data warehouse dikembangkan dengan menggunakan Oracle 11g. Selain itu, penelitian juga bertujuan untuk menggali informasi dan pengetahuan dengan basis data spasial. Penggalian data ini dilakukan menggunakan aplikasi WEKA dengan membandingkan algoritma clustering DBSCAN, K-Means, dan EM. Penggalian informasi dari data spasial ini diharapkan bisa menghasilkan peta wilayah yang menunjukkan tingkat penjualan produkproduk PT XXX, sehingga diharapkan perusahaan dapat lebih fokus dalam memasarkan produk yang dipercaya lebih unggul di suatu wilayah tertentu. Hasil penelitian menunjukkan bahwa Data warehouse yang dikembangkan sudah berhasil menampilkan yang diperlukan oleh manajemen yaitu pada jumlah stok ritel, nilai penjualan ritel, dan nilai penerimaan wesel.
\end{abstract}

Kata kunci: competitive advantage, DataWarehouse, teknik clustering, basis data spatial 


\section{PENDAHULUAN}

Perkembangan pasar yang bergerak menjadi sangat kompetitif dan persaingan bisnis yang semakin kompleks dan ketat telah menghadirkan tantangan baru bagi perusahaan. Kecepatan menjadi hal yang patut diperhatikan yaitu bagaimana cara perusahaan atau organisasi untuk mendapatkan dan mengevaluasi informasi dengan segera, dan untuk kemudian menggunakan informasi tersebut untuk merespon setiap kejadian dan masalah secara cepat dan tepat pula. Persaingan bisnis global pada saat ini mengarah pada perekonomian berbasis pelanggan (costumer based) sehingga mengakibatkan terjadinya pergeseran paradigma yang menuntut kesiapan perusahaan untuk bersaing memasuki pasar dengan cara menciptakan nilai (creating value) dari setiap proses dalam menghasilkan produk atau jasanya sesuai dengan harapan konsumen, sehingga bisa survive dan mencapai keunggulan bersaing (competitive advantage). Pada PT XXX merupakan salah satu perusahaan BUMN yang mengalami dampak persaingan bisnis. Salah satu yang terjadi adalah pada pengiriman wesel dan ritel. Kemajuan teknologi seperti ATM dan transfer pada perbankan membuat daya saing pada wesel dan ritel. PT XXX semakin dituntut untuk melakukan suatu perubahan.

Dunia bisnis yang penuh persaingan membuat para pelaku bisnis mulai memikirkan strategistrategi yang dapat menjamin kelangsungan bisnis perusahaan. Untuk mencapai hal itu, dapat dilihat tiga kebutuhan bisnis, yaitu: penambahan jenis maupun peningkatan kapasitas produk, pengurangan biaya operasi perusahaan, serta peningkatan efektifitas pemasaran dan keuntungan (kottler 2001). Untuk memenuhi kebutuhan-kebutuhan tersebut banyak cara yang dapat ditempuh. Salah satu cara yang bisa ditempuh adalah memikirkan solusi yang efektif dengan biaya yang minimal.

Informasi yang dapat digunakan untuk mengambil/membuat keputusan adalah informasi yang berkualitas. Menurut O’brien (2003) kualitas informasi terbagi atas tiga dimensi yaitu time dimension, content dimension dan form dimension.

Dimensi waktu (Time Dimension) dari kualitas informasi harus memenuhi unsur timeliness, currency, frekuensi, dan time period.Timeliness artinya informasi harus ada saat diperlukan.Currency artinya informasi harus up to date saat disediakan, Frequency artinya informasi harus disediakan sesering mungkin. Sedangkan Time Period maksudnya adalah informasi harus menyangkut perioda lalu, kini dan besok.

Accuracy, Relevance, Completeness, Conciseness, Scope, dan Performance merupakan unsur kualitas informasi dari Dimensi Isi (content dimension). Accuracy artinya informasi harus terbebas dari kesalahan sebab informasi yang salah menyebabkan manajemen akan membuat keputusan yang salah juga. Relevance adalah informasi harus sesuai kebutuhan pemakainya, misalnya informasi kerusakan komputer lebih relevan apabila diberikan kepada teknisi dibanding kepada bagian keuangan.Completeness adalah semua informasi yang diperlukan harus tersedia.Conciseness artinya hanya informasi yang dibutuhkan yang harus disediakan.Misalnya tidak semua informasi perlu disajikan ke manajer keuangan, karena informasi yang memenuhi conciseness hanya informasi mengenai transaksi keuangan saja. Scope adalah informasi memiliki ruang lingkup yang luas/sempit dan berfokus pada internal/eksternal.Unsur terakhir dari dimensi isi adalah performance yaitu informasi dapat menguak kinerja dengan mengukur aktivitas yang telah diselesaikan, perkembangan yang sudah dikerjakan, dan sumberdaya yang terlibat.

Dimensi bentuk (form dimension) terdiri atas Clarity, Detail, order, Presentation, dan Media.Pada Clarity informasi yang diberikan harus dikemas dalam bentuk yang mudah dipahami. Detail yaitu informasi harus dapat disediakan dalam bentuk detail ataupun ringkasan/rangkuman. Order artinya informasi dapat disusun dalam urutan tertentu. Presentation artinya informasi dapat dipaparkan dalam bentuk narasi, numerik, grafik, ataupun media bentuk lain. Media yaitu Informasi 
dapat disediakan dalam bentuk kertas cetakan, dokumen tayangan video, atau media lainnya.Ketiga dimensi dari kualitas informasi tersebut baru bisa dipenuhi apabila perusahaan sudah menggunakan teknologi informasi.

Bentuk-bentuk penelitian dalam perancangan data warehouse meliputi berbagai bidang. Datawarehouse dimanfaatkan untuk mendapatkan informasi kinerja dosen (jumlah mata kuliah yang diajarkan, jumlah kelulusan/ketidaklulusan), kinerjamahasiswa (jumlah mata kuliah yang lulus/tidaklulus disbanding mata kuliah yang diambil), summary tiap nilai mata kuliah yang memiliki nilai A, B, dan C, (Handojo dan Rostianingsih, 2004). Data warehouse juga digunakan di bidang medis untuk membantu menyediakan sumber data dalam infrastruktur Business Intelegent dunia medis. Business Intelegent dalam mengambil keputusan dalam memberikan tindakan terbaik terhadap pasien (Bhattacharyya, 2005). Operasional menyimpan data transaksi secara simultan, sehingga pertambahan data tidak bias dihindarkan. Semakin besar data tersimpan, akan mempengaruhi performance aplikasi,terutama modul reporting.

Handojo dan Rostianingsih (2004) melaporkan bahwa pada kasus implementasi data warehouse di Universitas Petra Surabaya, dengan adanya data warehouse, proses penyusunan laporan menjadi lebih sederhana, karena pengguna bisa melakukan customization report sesuai dengan yang diinginkan, sehingga tercipta efisiensi waktu dari yang sebelumnya satu bulan (dengan program tambahan) atau seminggu (manual) menjadi satu hari.

Ariana (2007) juga menyebutkan hal yang sama bahwa implementasi data warehouse dalam organisasinya (Universitas Nasional) membantu pengambil kebijakan. Pada kasus UNAS lebih spesifik digunakan untuk mengenali pola karakterisitik mahasiswa yang mengambil program peminatan tertentu di program studi Manajemen Perusahaan UNAS dengan dibantu data mining.

Perkembangan teknologi informasi dan komunikasi bagi industri jasa pos berdampak terhadap penurunan jasa pengiriman surat ataupun wesel. Selain itu kemajuan teknologi seperti ATM dan transfer pada perbankan menambah daya saing pada wesel dan ritel. Teknologi informasi berupa pengelolaan data produk wesel dan ritel perusahaan menjadi hal yang sangat penting.

Penelitian ini mengambil studi kasus pada PT XXX yang merupakan salah satu perusahaan BUMN yang berskala nasional dan mempunyai cabang tersebar diseluruh Indonesia. PT XXX adalah perusahaan yang bergerak di bidang mail, logistic dan jasa keuangan. Pada PT XXX pengelolaan data hanya untuk kebutuhan operasional sehingga banyak informasi dari data tersebut yang masih dapat diolah dapat menghasilkan suatu keuntungan bagi perusahaan. Apabila data terkait dengan produk layanan ritel dan wesel tersebut dikelola dengan baik, akan bisa memberikan keuntungan untuk perusahaan dalam meningkatkan nilai penjualan. Selama ini PT XXX hanya melihat dari pelaporan mengenai kondisi stok dan transaksi benda pos dari pihak ketiga (vendor) dan pelaporan penjualan wesel. Pelaporan tersebut hanya dilakukan secara periodik yang dilakukan oleh pihak ketiga (vendor) sehingga menyebabkan pihak manajemen membutuhkan waktu dalam membuat keputusan. Selain hal tersebut pihak manajemen tidak dapat meminta laporan yang sesuai karena membutuhkan proses waktu yang cukup lama.

Berdasarkan uraian diatas, pertanyaan penelitian yang ingin dijawab melalui penelitian ini adalah: "Bagaimana rancangan data warehouse yang sesuai untuk pelaporan wesel dan ritel pada PT XXX?”.

Tujuan dari penelitan ini adalah untuk mendapatkan pembelajaran dari suatu proses penerapan data warehouse, yaitu merancang data warehouse pada database produk wesel dan ritel yang sesuai dengan kebutuhan PT XXX. 


\section{METODE}

Metodologi yang digunakan dalam penelitian terbagi dalam beberapa tahap, yaitu: pengumpulan data, menelaah data dan perancangan data warehouse.

\section{Pengumpulan Data}

Tahap pertama dalam penelitian adalah pengumpulan data. Untuk keperluan tersebut penulis melakukan pengumpulan data dengan cara melakukan observasi ke obyek penelitian dan melakukan pengkajian dokumen atau literatur untuk menggali dokumen organisasi yang berkaitan, struktur organisasi, tugas dan gambaran proses bisnisnya.

Dalam penelitian ini penulis melakukannya dengan pendekatan top-down, pendekatan ini dimulai dengan mendefinisikan sasaran dan kebijakan organisasi kemudian dilakukan analisis kebutuhan informasi lalu turun ke pemrosesan transaksi. Sebelum mulai membuat data model untuk data warehouse, sebaiknya spesifikasi kebutuhan informasi dan data yang tersedia (sumber data) sudah harus diketahui. Input dari tahap ini adalah data dari system operasional yang terjadi di perusahaan.

\section{Kebutuhan Bisnis dan Informasi}

Pada tahap ini dilakukan analisis lebih dalam mengenai kebutuhan bisnis dan informasi yang diharapkan oleh manajemen perusahaan. Data yang telah dikumpulkan sebelumnya akan dijadikan sebagai masukan dalam proses analisis terhadap kebutuhan bisnis dan informasi tersebut.

\section{Perancangan Data warehouse}

Pada perancangan data warehouse, langkah pertama yang dilakukan adalah ekstraksi data dari database operasional dan sumber eksternal. Data tersebut kemudian dibersihkan untuk meminimalisasi error dan mengisikan informasi yang kurang jika dimungkinkan. Selanjutnya dilakukan proses transformasi untuk memperbaiki ketidakcocokan.Transformasi data biasanya dilakukan dengan mendefinisikan view relational pada table dalam sumber data. Loading data terdiri dari mematerialisasi view dan menyimpannya dalam data warehouse. Data yang dibersihkan dan ditransformasikan akhirnya di-load ke dalam datawarehouse. Setelah data di-load ke dalam warehouse, pengukuran tambahan harus dilakukan untuk menjamin data dalam warehouse di-refresh secara periodic untuk merefleksikan pembaruan sumber data dan secara periodic membuang data lama (mungkin ke dalam media pengarsipan).

Spesifikasi kebutuhan fungsional informasi secara teknis menyatakan data apa yang harus disimpan di dalam data warehouse untuk memenuhi analisis yang akan dilakukan oleh pemakai. Hal ini dapat dinyatakan dalam bentuk pertanyaan yang harus dapat dijawab oleh data di dalam data warehouse, seperti: (1) berapa jumlah tingkat penjualan barang pada bulan September hingga Desember, perbulan, pertahun (2) berapa barang yang berpotensi untuk menghasilkan (3) berapa jumlah asset, berapa jumlah customer yang kompeten untuk program promo dan lain sebagainya.

Penjelasan lebih detail dari masing-masing tahapan pada alur pengerjaan seperti metode yang digunakan berikut hasil dari masing-masing tahapan dapat dilihat pada Tabel 1 berikut ini: 
Tabel 1 Alur Pengerjaan

\begin{tabular}{ll}
\hline Tahap Pengumpulan Data & $\begin{array}{l}\text { Metode: Observasi,Studi literatur } \\
\text { Output: Rumusan masalah }\end{array}$ \\
\hline Analisa Kebutuhan Informasi Bisnis & $\begin{array}{l}\text { Metode:Analisa kebutuhan bisnis dan } \\
\text { informasi } \\
\text { Output:Kebutuhan bisnis dan informasi }\end{array}$ \\
\hline Perancangan Data warehouse & $\begin{array}{l}\text { Metode: Tahapan Data warehouse } \\
\text { Merancang arsitektur data warehouse } \\
\text { Menentukan table fakta dan tabel dimensi } \\
\text { Melakukan proses cleansing dan ETL } \\
\text { Melakukan perancangan OLAP } \\
\text { Output:Rancangan data warehouse }\end{array}$ \\
\hline
\end{tabular}

\section{HASIL DAN PEMBAHASAN}

\section{Perancangan Arsitektur Data Warehouse}

Untuk memulai perancangan arsitektur data warehouse, didefinisikan kebutuhan dari pengguna yang paling dibutuhkan dan data mana yang harus diutamakan. Rancangan arsitektur data warehouse dibagi menjadi dua, arsitektur logical dan arsitektur fisikal. Arsitektur logical adalah tahapan alur data dari sumber data yang digunakan sampai data warehouse yang digunakan, sedangkan arsitektur fisik adalah gambaran teknis dari konfigurasi yang diterapkan pada data warehouse.

\section{Arsitektur Logical}

Perancangan arsitektur logical pada data warehouse.Sumber data yang digunakan adalah sumber data yang diperoleh dari dataoperasional layanan.RDBMS, yang digunakan untuk penyimpanan data operasional layanan. Dari sumber data ODS (Operational Data Store) dilakukan proses selection. Proses selection yaitu proses pemilihan data yang diperlukan dalamsistem data warehouse dari sumber data. Tidak semua data dari sumber datadigunakan untuk data warehouse, untuk itulah proses selection dilakukan. Prosesselanjutnya setelah selection adalah extraction, memindahkan data yang sudahdipilah kedalam sistem database yang terpisah dari sistem database operasional.Pemisahan database ini adalah agar sistem operasional tidak terganggu olehproses dalam data warehouse.Data yang sudah terseleksi kemudian dilakukan proses dilakukan proses cleansing, yaitu proses pembersihan data dan proses tranformasi yang keduaproses tersebut dilakukan data staging atau temporary database. Kemudian proses loading, yaitu proses memasukan data hasil proses sebelumnya ke dalam data warehouse. Aliran data dari arsitektur logical tersebut dapat dilihat pada Gambar 1.

\section{Pengambilan dan pengumpulan data (extract)}

Database layanan wesel dan ritel menggunakan platform Oracle 11g. Begitu juga database yang digunakan untuk data staging dan data warehouse akan menggunakan Oracle 11g. Kesamaan platform database ini dipilih dengan pertimbangan karena pengembangan kedepan dan lisensi yang dimiliki saat ini adalah Oracle.User yang dapat mengakses sistem data warehouse adalah user yang terhubung dengan web server. Dengan bantuan dari admin PT XXX, data operasional yang tersimpan 
di database dapat diberikan berupa tabel-tabel berdasarkan kebutuhan penelitian tentang wesel dan ritel dengan dasar kerahasiaan perusahaan.

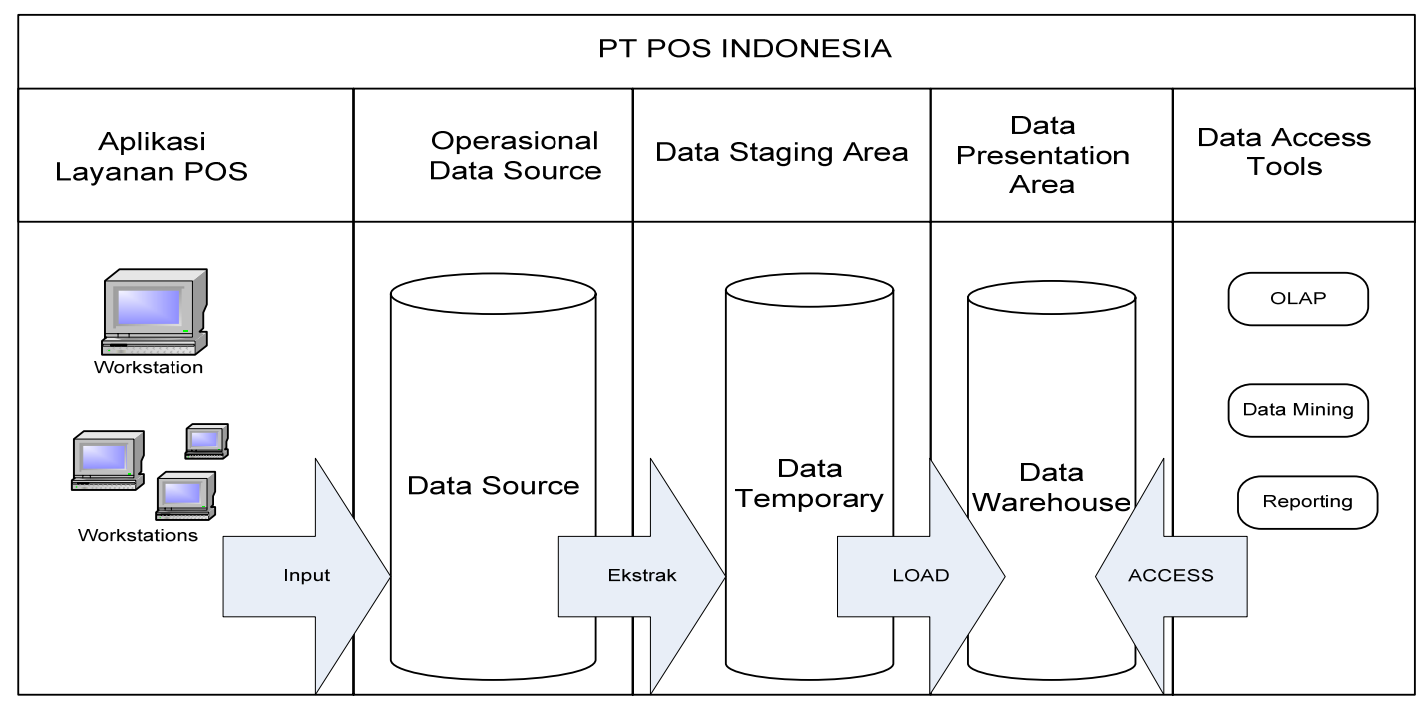

Gambar 1 Arsitektur logical wesel dan penerimaan wesel.

Data yang diambil ini adalah merupakan data yang sesuai permintaan penelitian. Pemilihan tabel-tabel ini dilihat dari laporan yang ada.Setelah pemilihan table dalam basis data selanjutnya memasukkan ke dalam oracle $11 \mathrm{~g}$ sebagai media untuk staging. Penelitian ini menggunakan sebuah data source yang telah memiliki keseragaman untuk format data yang digunakan di seluruh cabang. Kemungkinan terjadi data yang berulang jarang sekali, dikarenakan operasional sudah terintegrasi dengan baik.Berikut sumber data penelitian pada basis data operasional layanan.

Jumlah table operasional adalah 157 tabel dengan total kolom 1865 dan ukuran data saat dilakukan penelitian ini adalah 200gigabytes. Dari 107 tabel tersebut tidak semua table akan disimpan dalam data warehouse dan dari masing- masing table yang digunakan, tidak semua kolom akan disimpan. Tabel-tabel yang diproses dan disimpan dalam data warehouse adalah table pelanggan, produk, waktu, wesel_receive_live, unitbisnis, status saldo, kantor, kantor ritel, supplier, penj_ritel_live.

\section{Perancangan Star Schema}

Pada tahap data staging, dilakukan proses selection, filtering, editing, summarizing, combining, dan loading data tersebut terhadap sumber data untuk mempersiapkan data dalam pemprosesan lebih lanjut ke data warehouse. Untuk itu diperlukan perancangan model data warehouse berupa star schema. Berikut ini rancangan star schema yang akan dilakukan sebelum ekstraksi terhadap kebutuhan data: Wesel - penerimaan wesel yang dilakukan dituntut untuk selalu memberikan pelayanan yang terbaik. Persaingan yang semakin meningkat membuat sebuah produk pelayanan harus mempunyai suatu kualitas yang baik. Pelayanan produk wesel dimulai dari pelanggan melakukan transaksi pengiriman uang melalui kantor pos. produk layanan yang ditawarkan cukup beragam mulai dari wesel standar, prima, instan, ataupun berlangganan. Pelanggan diberikan menulis alamat tujuan dan nama pengirim dan dikirim. Selanjutnya petugas pos melakukan input data dan checker apabila terjadi kesalahan. Biasanya sering terjadi human error seperti alamat yang tidak lengkap. Dari sisi perusahaan kesalahan yang terjadi seperti kurang nya petugas pengantar, sosialisasi pemberitahuan bahwa terdapat wesel yang telah terkirim dan masuk. PT XXX sendiri sudah 
mempunyai system aplikasi untuk wesel yang berbasis web base. System aplikasi tersebut terintegrasi dengan kantor yang lain dan system aplikasi pos tersebut dapat juga dengan system offline apabila tutup kantor dan selesai seluruh transaksi dilakukan baru dilakukan pengiriman data transaksi wesel ke kantor pusat. Gambar 2 menunjukan star schema yang terdiri dari lima dimensi yaitu dimensi pelanggan, dimensi status saldo, dimensi unit bisnis, dimensi kantor, dimensi produk, dimensi status wesel dan satu buah table fakta.

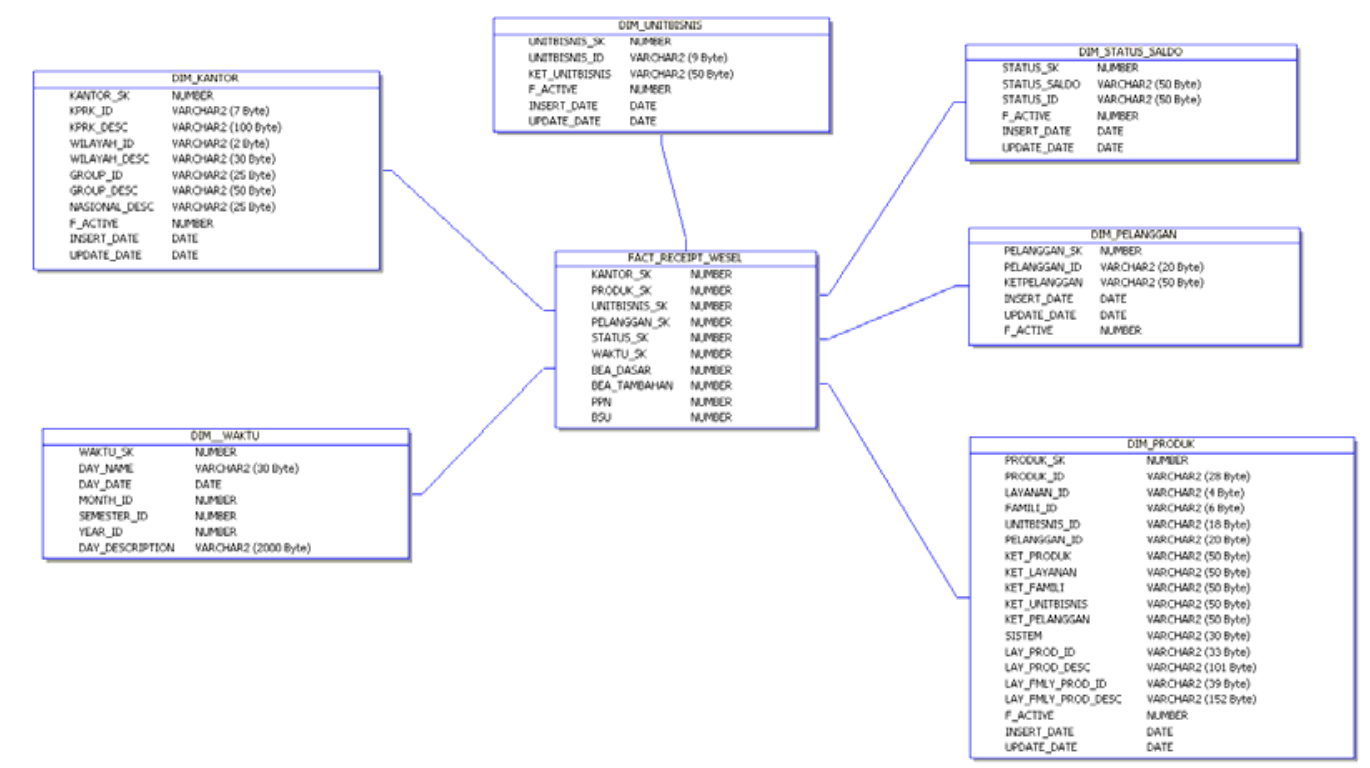

Gambar 2 Model star schema untuk penerimaan wesel.

Stok Ritel - dilihat dari dimensi produk barang dan kantor ritel. Kantor ritel melakukan request barang terhadap suplier dan melihat penjualan dari produk. Dimensi kantor ritel akan mengecek stok yang ada pada setiap kantor (Gambar 3).

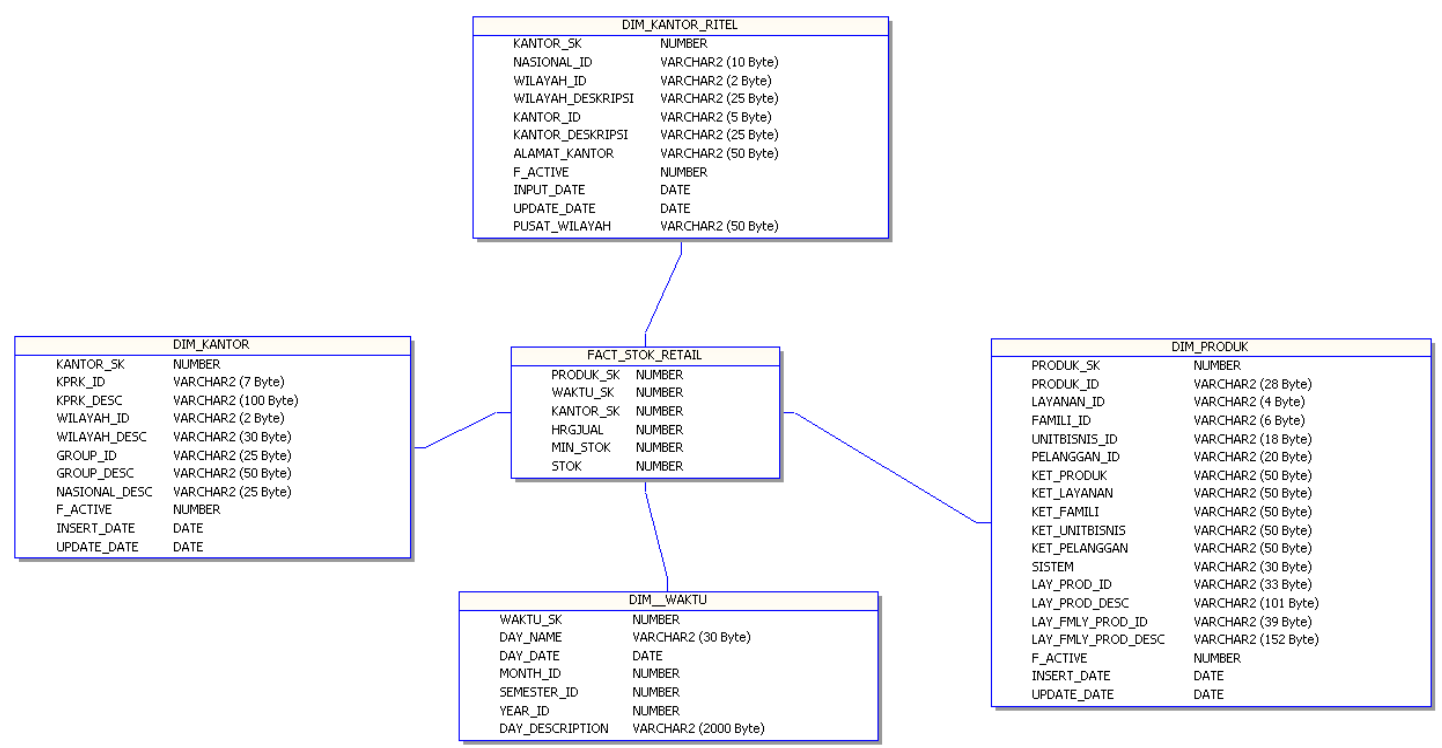

Gambar 3 Model Star Schema untuk Stok Ritel 
Penjualan Ritel - penjualan produk merupakan salah satu pokok dari usaha perusahaan selain memberikan pelayanan jasa terhadap pelanggan. Didalam penjualan ritel terdapat sebuah pola kerjasama dengan membagi pola kerja sama untuk memperkuat sector penjualan. Dalam tebel fakta terdapat enam buah dimensi yaitu dimensi supplier, dimensi pelanggan, dimensi unit bisnis, dimensi kantor, dimensi produk dan dimensi waktu (Gambar 4).

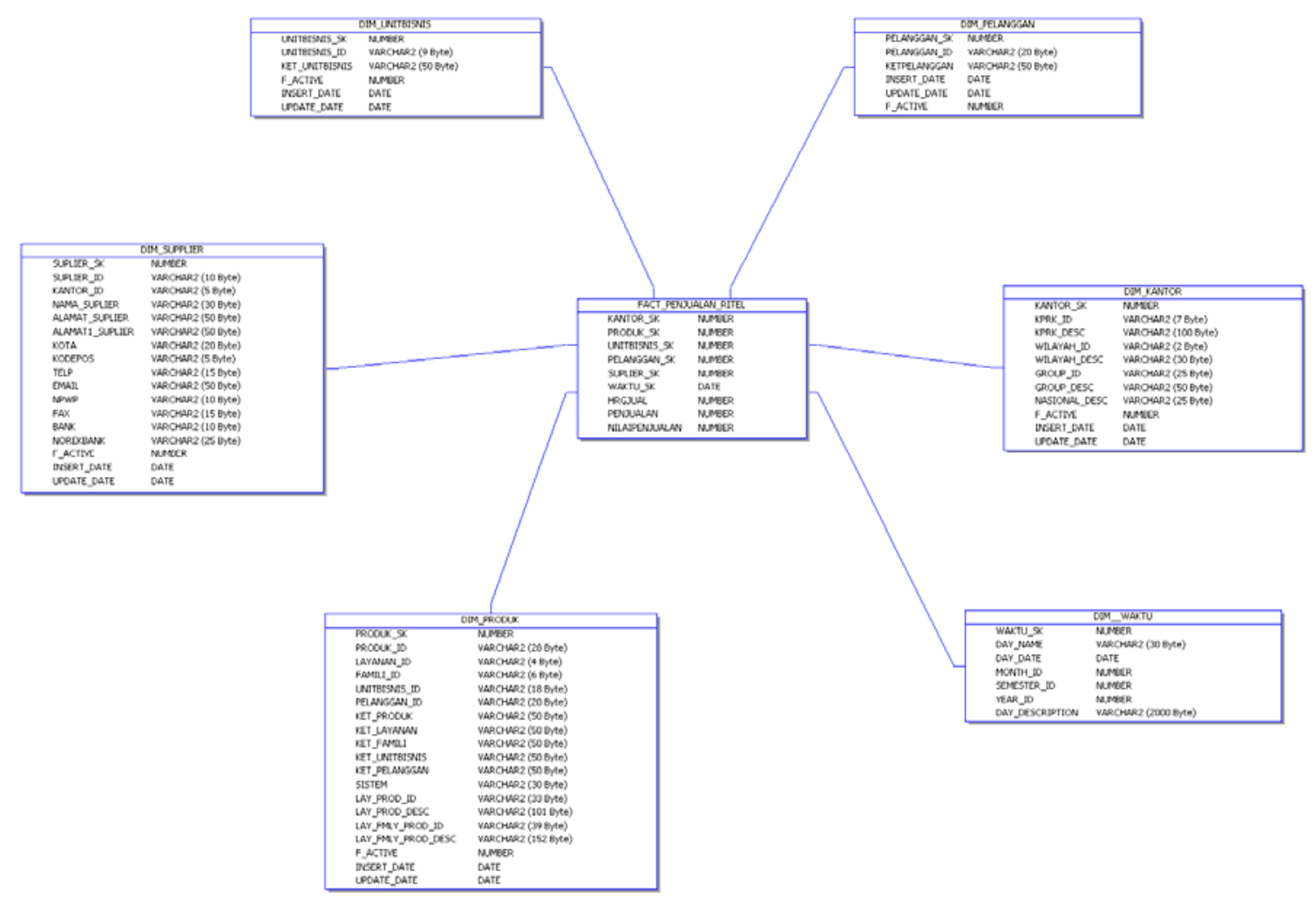

Gambar 4 Model star schema untuk penjualan ritel.

Ekstrak data dari basis data operasional layanan ke oracle $11 \mathrm{~g}$ enterprise edition. Dengan platform yang sama tidak diperlukan perubahan pada sisi struktur data. Tahapan dari ekstrak dilakukan dari sumber data yang digunakan melalui proses pemilihan data yang kemudian disimpan pada temporary database. Penempatan temporary database diletakkan pada penyimpanan database, mesin dan platform yang sama dengan data warehouse agar proses ETL dapat dilakukan lebih cepat dan tidak mengganggu proses operasional.

Tahapan data cleansing tidak dilakukan terhadap data karena penelitian ini menggunakan sebuah data source yang telah memiliki keseragaman format data yang digunakan seluruh cabang PT XXX.

\section{Transformasi Data (Transforming) dan Penyimpanan Data (Loading)}

Tahapan transformation pada prinsipnya mengubah bentuk data dari data yang telah di-extract menjadi bentuk yang sesuai dengan kebutuhan pengguna. Proses ini dilakukan setelah data yang ada sudah melewati proses ekstraksi dan pembersihan. Proses transformasi yang dilakukan dibagi berdasarkan level, yaitu record-level dan field-level. Pada proses ini dilakukan proses pemilihan, penggabungan dan agregasi untuk mendapatkan data ringkasan sesuai dengan dimensi yang akan dibuat. Proses transformasi membutuhkan waktu dalam membuat prosedur dalam SQL. Pada tabel 
wesel proses transforming dilakukan pengambilan tabel dan denormalisasi mulai dari pelanggan, wilayah, kantor, produk dan tarif penjualan.

Proses yang dilakukan pada tahap akhir adalah pemuatan data (loading). Data yang digunakan pada tahap ini merupakan data dari proses-proses yang dilakukan sebelumnya, yaitu ekstraksi, pembersihan (cleansing), dan transformasi ke dalam data. Loading merupakan proses pengisian data ke dalam tabel yang sesuai dengan kebutuhan data yang dianalisa.

\section{Presentasi Data Warehouse}

Kemampuan data warehouse dalam menyajikan informasi pada pengguna adalah hal yang paling penting. Penggunaan tools dalam presentasi data perlu dipertimbangkan hal-hal seperti fitur yang ada, biaya saat development dan maintain setelah data warehouse beroperasi. Tools yang digunakan sebisa mungkin tidak terikat (loosely coupled) pada satu platform database supaya pengembangan di layer bisnis tidak perlu mengubah mengubah terlalu banyak arsitektur dibawahnya (separation of concern).

Tools yang digunakan pada penelitian ini adalah Mondrian.Mondrian adalah OLAP engine yang menggunakan bahasa pemrograman java.Mondrian digunakan untuk analisis interaktif dari database yang besar, menggunakan bahasa MDX (Multi Dimensional eXpression) untuk mengeksekusi Query. MDX merupakan query yang digunakan untuk data multidimensional dan menggunakan sintaks yang sama dengan SQL. Perbedaannya adalah SQL digunakan untuk query relational table sedangkan MDX digunakan untuk query multidimensional table.

Kemampuan Mondrian dalam berintergrasi dengan berbagai platform database memberi kebebasan bagi pengembang data warehouseuntuk memilih database sesuai dengan kebutuhan dan mengurangi ketergantungan pada satu vendor saja (vendor lock-in). Meskipun tools ini bersifat open source danpenggunaan tools yang bersifat open source tetapi Mondrian memilikikemampuan yang baik sebagai OLAP engine dalam melakukan presentasi data warehouse.

Rancangan pelaporan dirancang dalam keseragaman laporan OLAP. Pada produk layanan wesel kebutuhan manajemen dapat melihat dan menilai seluruh wilayah dan cabang dimana mengetahui ,produk, jumlah setor wesel, dan jumlah transaksi yang dapat dimanfaatkan dalam laporan penjualan, tingkat penjualan wesel, laporan produk wesel, dan laporan status penerimaan wesel.

Pada rancangan terhadap stok ritel terdapat laporan untuk jumlah stok yang tersedia dengan melihat setiap cabang dan wilayah.Pada stok barang terdapat supplier dan tingkat minimal stok yang tersedia sehingga kapasitas penyimpanan setiap cabang dapat terjaga.

Pada rancangan terhadap jumlah dan tingkat penjualan ritel terdapat laporan penjualan untuk setiap cabang yang terdiri dari nilai penjualan dan penjualan per unit.Pada penjualan ritel dapat melihat produk ritel dengan penjualan terbaik di setiap cabang dan juga dapat melihat unit dari barang dalam setiap cabang.

\section{Penyetoran Wesel}

Gambar 5 menunjukan table fakta untuk penyetoran wesel yaitu tabel penyetoran_wesel yang dikenali sebagai cube oleh perangkat lunak Schema Workbench. Pengukuran (measure) pada tabel fakta ini adalah jumlah total penyetoran dan jumlah transaksi. Penyetoran wesel merupakan tingkat penjualan pada produk pelayanan wesel. Dari sini dapat dilihat bahwa setiap penyetoran yang dilakukan pada setiap cabang. Berikut adalah contoh informasi penyetoran wesel. 
Gambar 6 menunjukan keberhasilan dalam pembentukan OLAP bahwa tidak ada kesalahan atau error terhadap cube yang telah tercipta. Sedangkan Gambar 7 merupakan hasil implementasi terhadap cube dengan nama penyetoran_wesel.

Dalam laporan OLAP diatas digambarkan kemampuan dari teknologi Mondrian yang bisa melakukan drilldown dan rollup.

\section{Stok Ritel}

Pada Gambar 8 digambarkan pembentukan cube stok ritel yang terdiri dari tabel fakta stok ritel, tiga buah dimensi dan dua buah pengukuran (measure). Measure yang dimaksud yaitu pengukuran (measure) jumlah stok barang yang tersedia dan pengukuran (measure) jumlah minimal stok setiap cabang. Jumlah minimal stok barang ritel ini terdapat limit minimal yang sudah ditentukan oleh setiap cabang dalam setiap stoknya. Gambar 9 menggambarkan keberhasilan pembentukan cube tidak terjadi kesalahan dalam mengeksekusi query. Terdapat dua buah dimensi kolom sebagai pengukuran kemudian tiga buah baris yaitu kantor, produk, dan waktu. Gambar 10 menampilkan hasil yang dibentuk dari cube dengan menggunakan teknologi Mondrian.

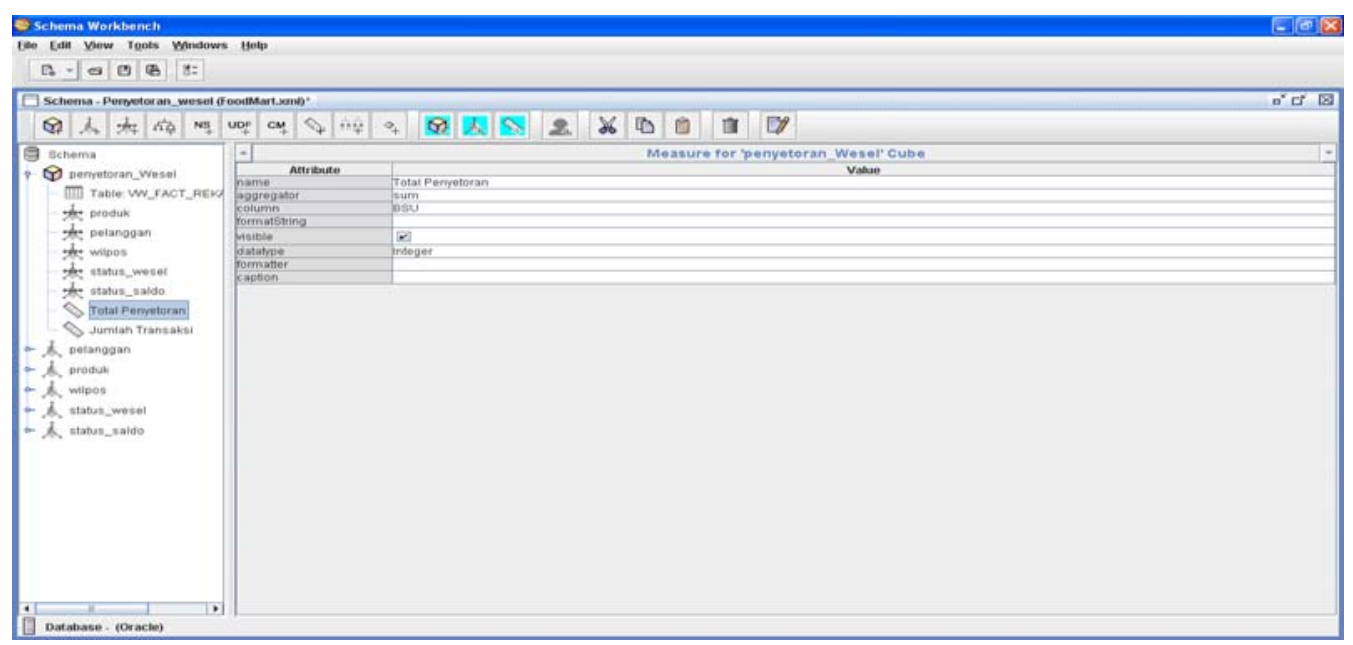

Gambar 5 Desain OLAP untuk penyetoran wesel.

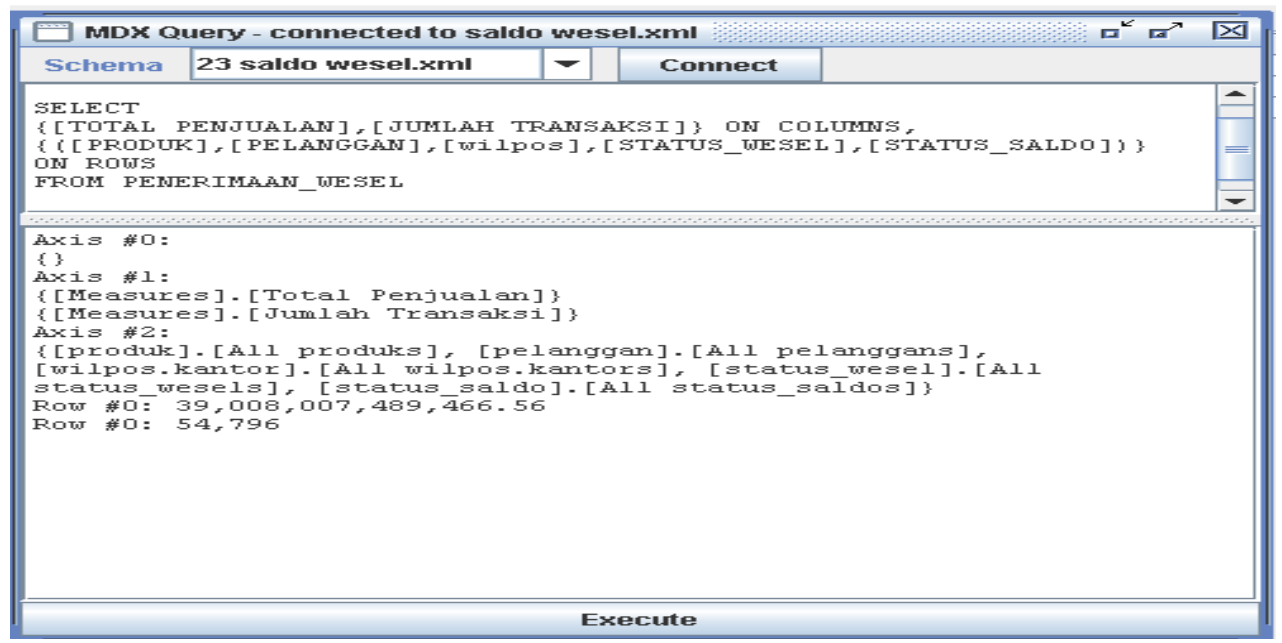

Gambar 6 MDX Query terhadap penyetoran wesel. 


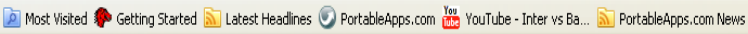

Penyetoran wesel OLAP

\section{回|}

\begin{tabular}{|c|c|c|c|c|c|c|}
\hline \multirow[b]{2}{*}{ produk } & \multirow[b]{2}{*}{ pelanggan } & \multirow[b]{2}{*}{ kantor } & \multirow[b]{2}{*}{ status_wesel } & \multirow[b]{2}{*}{ status_saldo } & \multicolumn{2}{|l|}{ Measures } \\
\hline & & & & & - Total Penjualan & - Jumlah Transaksi \\
\hline \multirow[t]{15}{*}{-All produks } & \multirow[t]{15}{*}{ +All pelanggans } & -All wilpos.kantors & +All status_wesels & +All status_saldos & $39,008,007,489,466.56$ & 54,796 \\
\hline & & \#null & +All status_wesels & +All status_saldos & $19,968,158,000$ & 216 \\
\hline & & Kantor Pusat & +All status_wesels & +All status_saldos & $37,591,235,584$ & 104 \\
\hline & & NA & +All status_wesels & +All status_saldos & $12,795,209,590,982.56$ & 816 \\
\hline & & Wilpos I Medan & +All status_wesels & +All status_saldos & $962,463,074,236$ & 4,192 \\
\hline & & Wilpos II Padang & 4All status_wesels & +All status_saldos & $3,688,931,932,764$ & 3,880 \\
\hline & & Wilpos III Palembang & +All status_wesels & +All status_saldos & $3,682,985,568,568$ & 4,028 \\
\hline & & Wilpos IV Jakarta & 4All status_wesels & +All status_saldos & $5,110,879,599,648$ & 6,720 \\
\hline & & Wilpos IX Banjarbaru & +All status_wesels & +All status_saldos & $5,347,815,416,100$ & 4,736 \\
\hline & & Wilpos V Bandung & 4All status_wesels & +All status_saldos & $1,105,671,352,388$ & 4,980 \\
\hline & & Wilpos VI Semarang & +All status_wesels & +All status_saldos & $1,434,171,320,728$ & 8,912 \\
\hline & & Wilpos VII Surabaya & 4All status_wesels & +All status_saldos & $1,557,202,972,004$ & 8,024 \\
\hline & & Wilpos VIII Denpasar & 4All status_wesels & +All status_saldos & $686,042,857,492$ & 3,060 \\
\hline & & Wilpos X Makasar & +All status_wesels & +All status_saldos & $713,111,774,104$ & 2,892 \\
\hline & & Wilpos XI Jayapura & +All status_wesels & +All status_saldos & $1,865,962,636,868$ & 2,236 \\
\hline BUMN BKLT & +All pelanggans & +All wilpos.kantors & +All status_wesels & +All status_saldos & $8,470,000,000$ & 24 \\
\hline CHEVRON PACIFIC INA & +All pelanggans & 4All wilpos.kantors & 4All status_wesels & +All status_saldos & $2,859,040,000$ & 64 \\
\hline DUPONT & *All pelanggans & 4All wilpos.kantors & +All status_wesels & +All status_saldos & $78,025,036,692$ & 20 \\
\hline EKS SIMWESPOS & +All pelanggans & 4All wilpos.kantors & 4All status_wesels & +All status_saldos & $37,591,235,584$ & 104 \\
\hline INFAQ SHADAQAH & +All pelanggans & 4All wilpos.kantors & 4All status_wesels & +All status_saldos & $13,376,000$ & 160 \\
\hline INSTAN & +All pelanggans & 4All wilpos.kantors & 4All status_wesels & +All status_saldos & $16,011,938,655,760$ & 10,516 \\
\hline JAMSOSTEK & +All pelanggans & 4All wilpos.kantors & +All status_wesels & +All status_saldos & $399,200,000$ & 24 \\
\hline
\end{tabular}

Gambar 7 Contoh report penyetoran wesel.

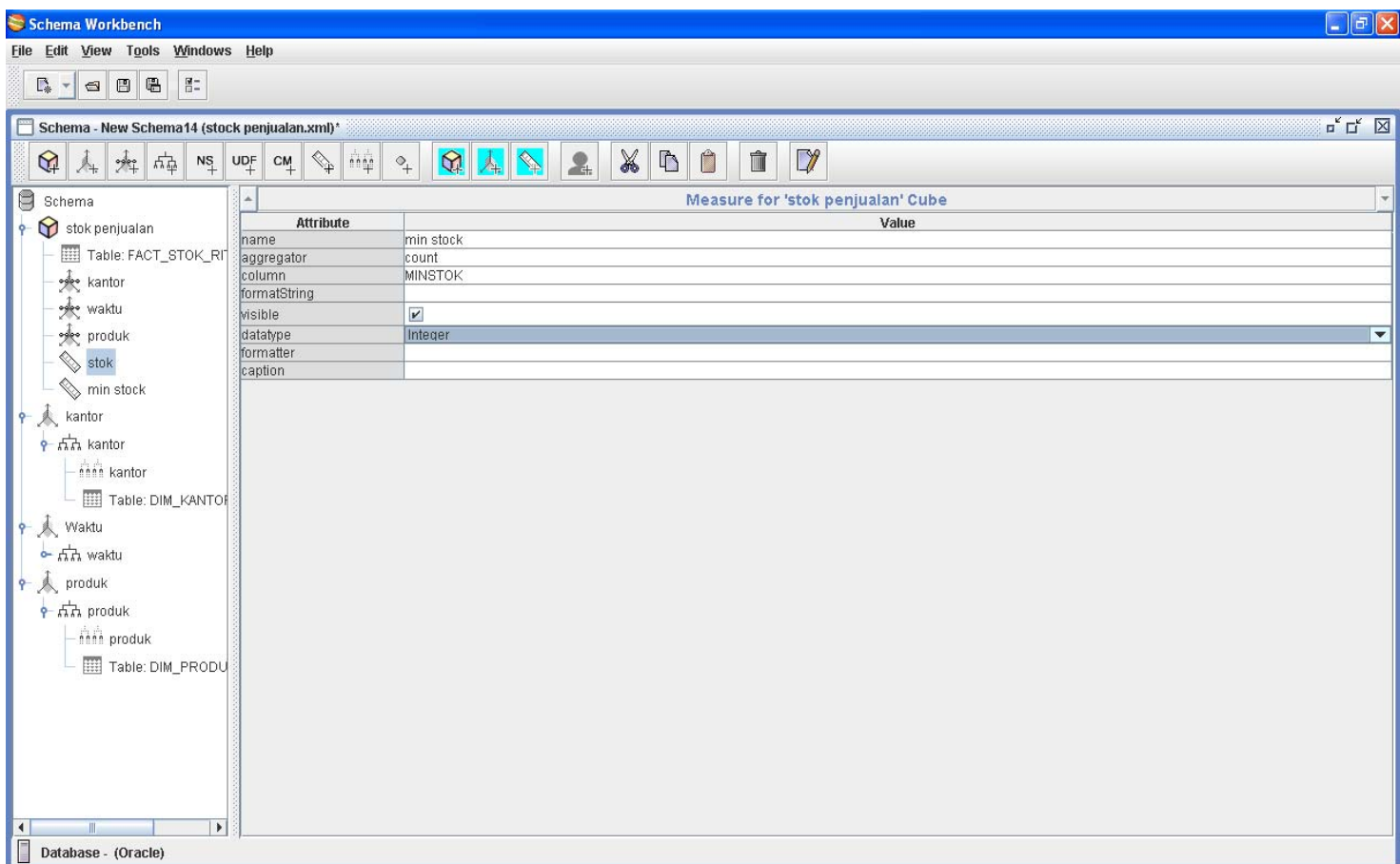

Gambar 8 Desain OLAP untuk stok ritel. 


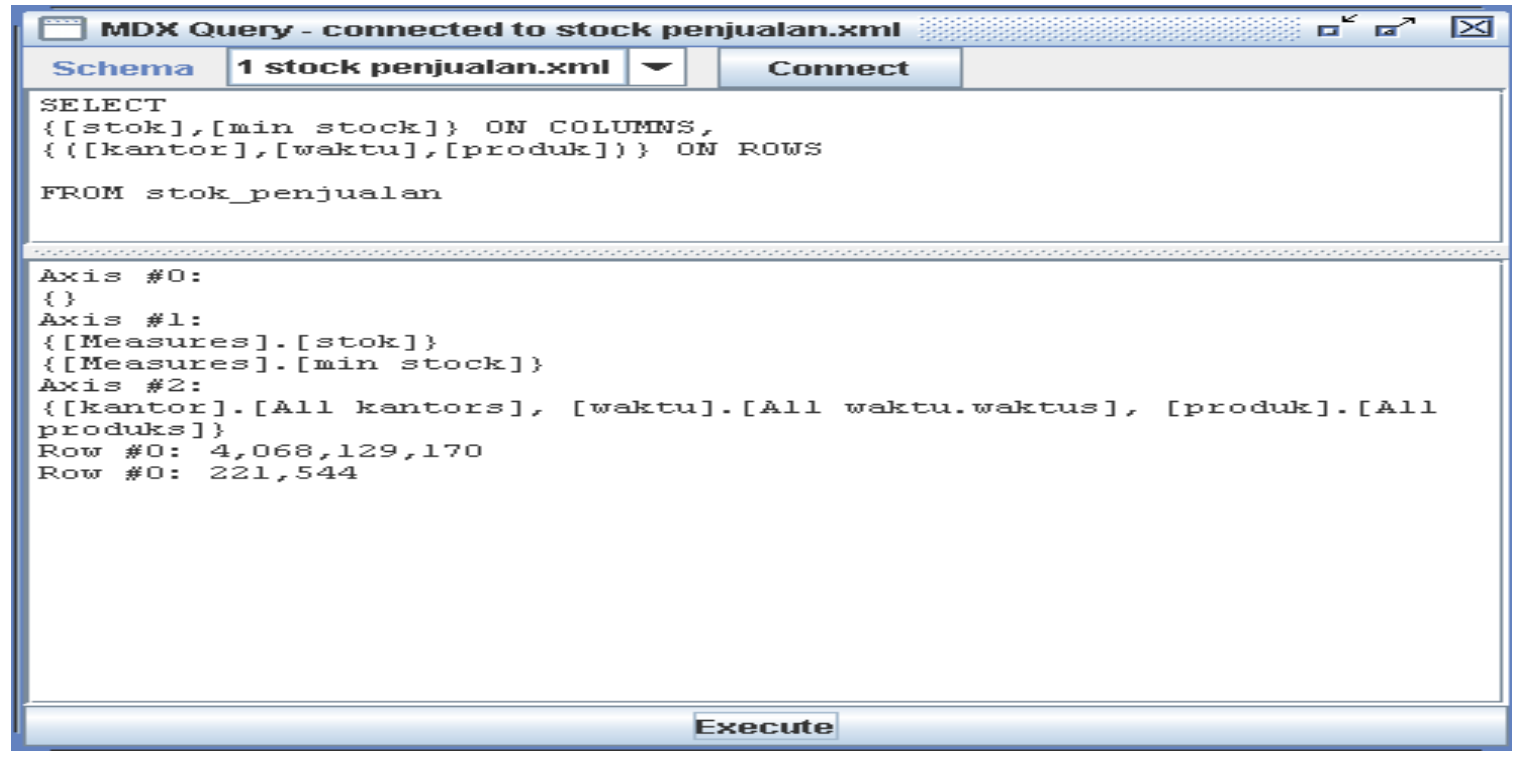

Gambar 9 MDX Query terhadap stock ritel.

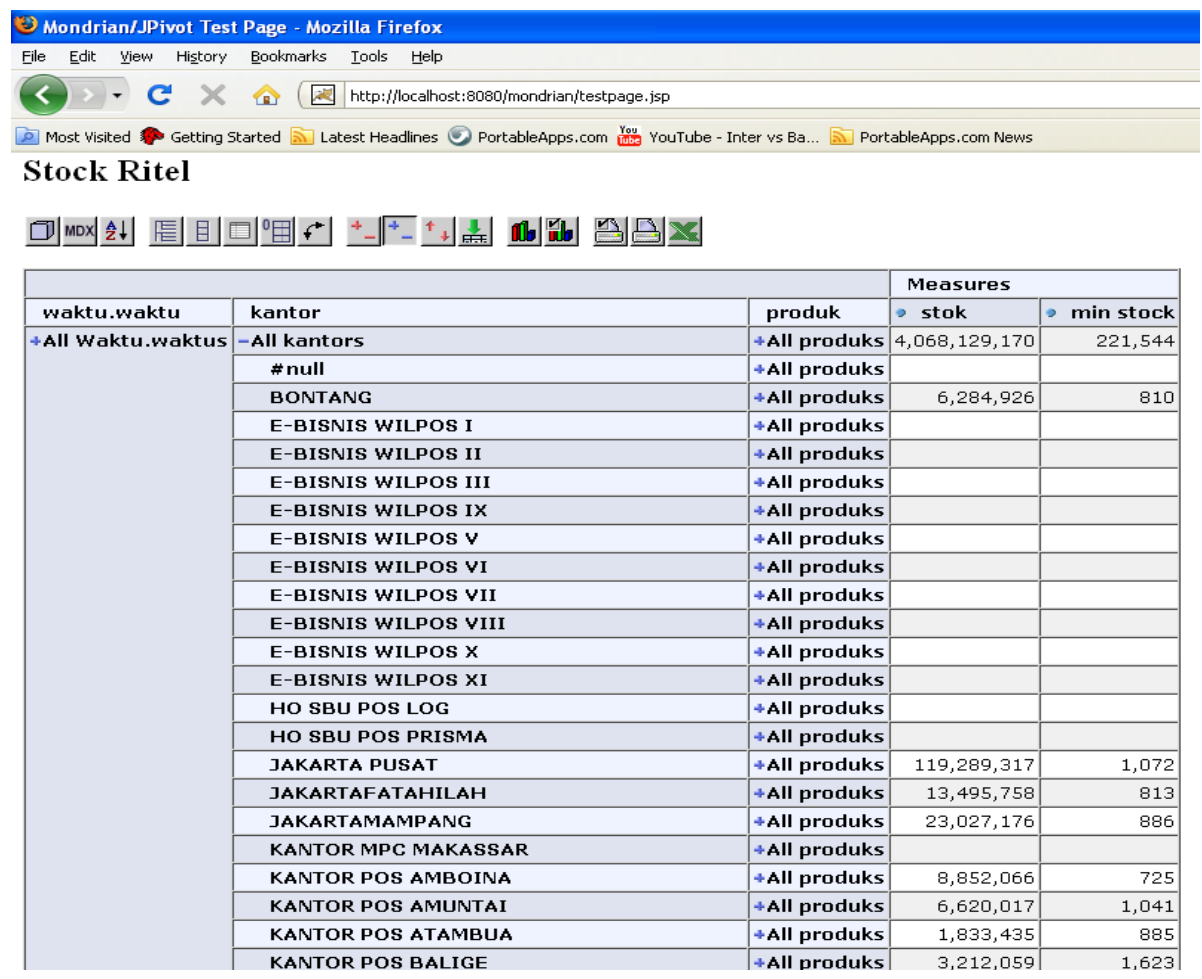

Gambar 10 Laporan OLAP untuk stok ritel.

\section{Penjualan Ritel}

Pada Gambar 11 digambarkan pembentukan cube penjualan ritel yang terdiri dari tabel fakta stok ritel, enam buah dimensi dan dua buah pengukuran (measure). Measure yang dimaksud adalah penjualan per unit dan pengukuran (measure) nilai penjualan setiap cabang. Laporan untuk nilai penjualan dapat dilakukan per unit produk sehingga manajemen dapat mengetahui setiap produk ritel 
dengan wilayah setiap cabang beserta produk dan nilai penjualannya per unit. Gambar 12 menggambarkan keberhasilan pembentukan cube tidak terjadi kesalahan dalam mengeksekusi query. Terdapat dua buah dimensi kolom sebagai pengukuran kemudian enam buah baris yaitu kantor, produk, pelanggan, unit bisnis, waktu, dan supplier. Gambar 13 menampilkan hasil yang dibentuk dari cube dengan menggunakan teknologi Mondrian.

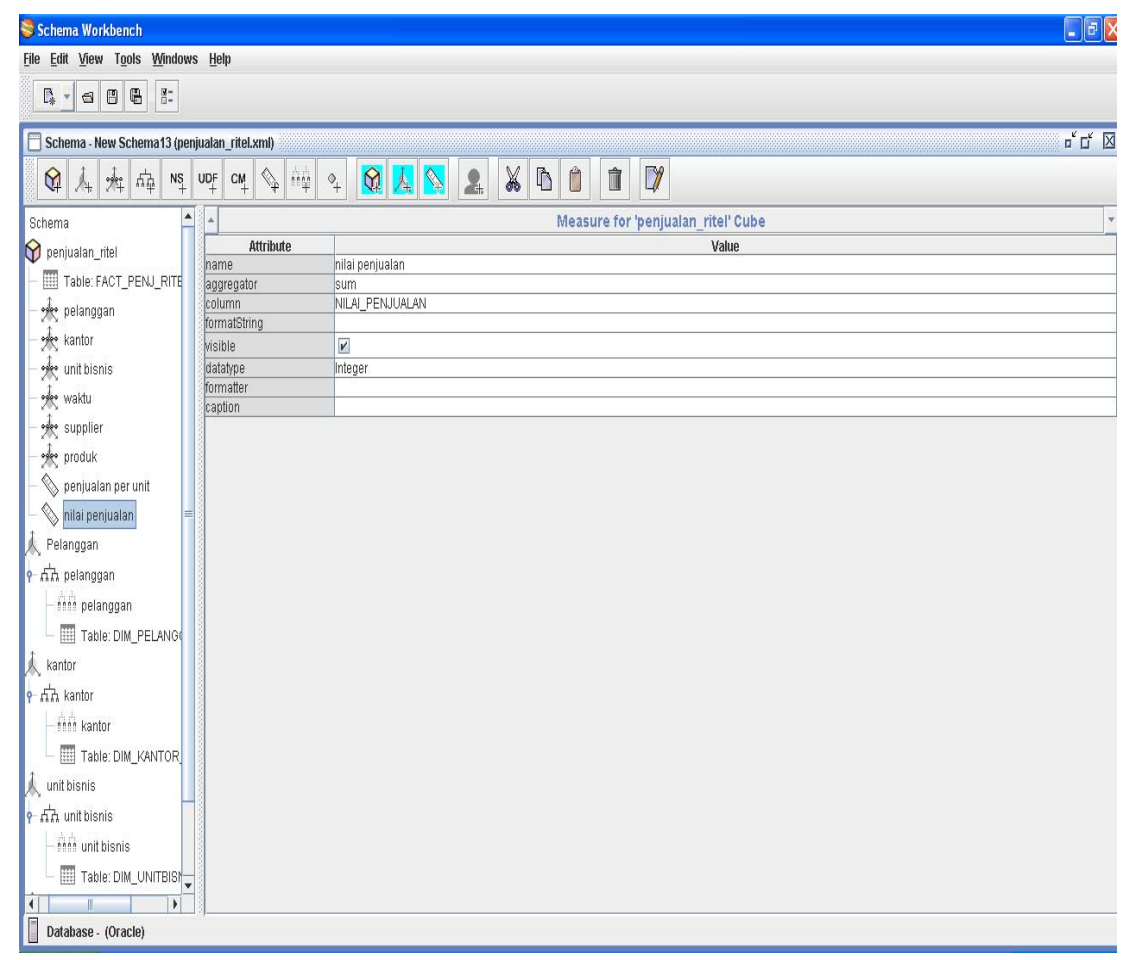

Gambar 11 Desain OLAP untuk penjualan ritel.

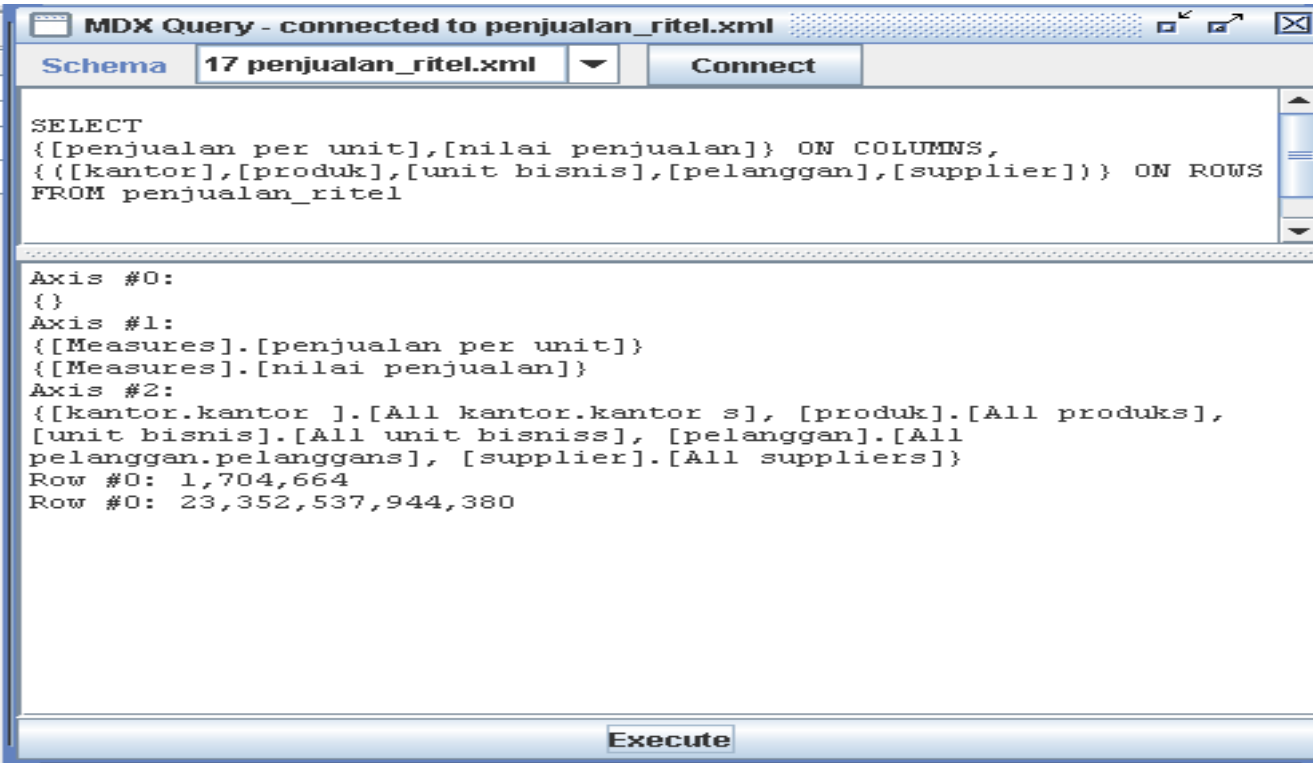

Gambar 12 MDX Query terhadap penjualan ritel 


\begin{tabular}{|c|c|c|c|c|c|c|}
\hline \multicolumn{7}{|c|}{ Eile Edit View History Bookmarks Iools Help } \\
\hline \multicolumn{7}{|c|}{ (4) C X \& 图 http://llocalhost:8080/mondrian/testpage.jsp } \\
\hline \multicolumn{7}{|c|}{ Penjualan Ritel OLAP } \\
\hline \multicolumn{7}{|c|}{ 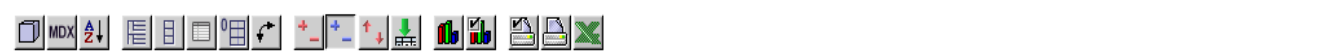 } \\
\hline \multicolumn{7}{|c|}{ Measures } \\
\hline kantor & produk & unit bisnis & pelanggan.pelanggan & supplier & - penjualan per unit & 2 nilai penjualan \\
\hline -All kantor.kantor s & 4All produks & +All unit bisniss & +All Pelanggan.pelanggans & $\div$ All suppliers & $1,704,664$ & $23,352,537,944,380$ \\
\hline AMBON & +All produks & 4All unit bisniss & 4All Pelanggan.pelanggans & +All suppliers & 4,472 & $72,335,610,000$ \\
\hline AMUNTAI & +All produks & +All unit bisniss & +All Pelanggan.pelanggans & +All suppliers & 8,040 & $57,108,800,000$ \\
\hline ATAMBUA & +All produks & +All unit bisniss & 4All Pelanggan.pelanggans & +All suppliers & 4,544 & $22,267,088,000$ \\
\hline BALIGE & +All produks & + All unit bisniss & 4All Pelanggan.pelanggans & +All suppliers & 5,468 & $17,685,396,400$ \\
\hline BALIKPAPAN & +All produks & 4 All unit bisniss & +All Pelanggan.pelanggans & +All suppliers & 8,740 & $182,216,756,000$ \\
\hline BANDAACEH & +All produks & $\div$ All unit bisniss & +All Pelanggan.pelanggans & +All suppliers & 6,896 & $148,445,923,200$ \\
\hline BANDUNG & +All produks & AAll unit bisniss & +All Pelanggan.pelanggans & +All suppliers & 15,576 & $736,148,056,000$ \\
\hline BANGKALAN & +All produks & +All unit bisniss & +All Pelanggan.pelanggans & +All suppliers & 10,072 & $39,261,324,000$ \\
\hline BANGKINANG & +All produks & +All unit bisniss & 4All Pelanggan.pelanggans & +All suppliers & & \\
\hline BANJAR & +All produks & + All unit bisniss & +All Pelanggan.pelanggans & +All suppliers & 8,892 & $48,537,300,400$ \\
\hline BANJARBARU & +All produks & + All unit bisniss & +All Pelanggan.pelanggans & +All suppliers & 7,072 & $65,986,198,000$ \\
\hline BANJARMASIN & +All produks & +All unit bisniss & +All Pelanggan.pelanggans & +All suppliers & 8,484 & $158,465,466,800$ \\
\hline BANJARNEGARA & +All produks & +All unit bisniss & +All Pelanggan.pelanggans & +All suppliers & 12,636 & $44,357,246,000$ \\
\hline BANTAENG & +All produks & +All unit bisniss & +All Pelanggan.pelanggans & +All suppliers & & \\
\hline BANTUL & +All produks & +All unit bisniss & +All Pelanggan.pelanggans & +All suppliers & 11,868 & $42,298,978,000$ \\
\hline BANYUWANGI & +All produks & +All unit bisniss & +All Pelanggan.pelanggans & +All suppliers & 9,780 & $99,365,964,400$ \\
\hline BARABAI & +All produks & + All unit bisniss & 4All Pelanggan.pelanggans & +All suppliers & & \\
\hline BARRU & +All produks & + All unit bisniss & +All Pelanggan.pelanggans & +All suppliers & & \\
\hline BATAM & +All produks & 4 All unit bisniss & +All Pelanggan.pelanggans & +All suppliers & 12,392 & $248,769,310,000$ \\
\hline BATU & +All produks & + All unit bisniss & +All Pelanggan.pelanggans & +All suppliers & & \\
\hline BATURAJA & +All produks & +All unit bisniss & +All Pelanggan.pelanggans & +All suppliers & 9,208 & $63,815,048,000$ \\
\hline BATUSANGKAR & +All produks & + All unit bisniss & +All Pelanqqan.pelanqqans & +All suppliers & & \\
\hline
\end{tabular}

Gambar 13 Laporan OLAP untuk penjualan ritel.

Pada keseluruhan OLAP ini dapat langsung dilakukan ekspor data ke dalam bentuk file xls dengan menggunakan fitur dari teknologi Mondrian.

\section{PENUTUP}

Kesimpulan yang dapat diambil dari perancangan data warehouse adalah penulis telah berhasil merancang data warehouse yang mampu menampilkan laporan yang diperlukan oleh manajemen yaitu pada jumlah stok ritel, nilai penjualan ritel, dan nilai penerimaan wesel. Dengan adanya laporan ini diharapkan manajemen dapat membuat keputusan lebih cepat dan akurat.

\section{DAFTAR PUSTAKA}

Handojo, Andreas dan Rostianingsih, Silvia. (2004). Pembuatan Data Warehouse Pengukuran Kinerja Proses Belajar Mengajar di Jurusan Teknik Informatika Universitas Kristen Petra. Jurnal Informatika, 5(1), 53-58.

O'Brien, James A. (2003). Introduction to Information System: Essential for the e-Business Enterprise (Eleventh Edition). New York: McGraw-Hill Irwin. 